\title{
ANALISIS KUALITAS PELAYANAN PARKIR DENGAN METODE SERVQUAL, IPA DAN QFD UNTUK MENINGKATKAN KEPUASAN PELANGGAN DI PT. SECURINDO PACKATAMA INDONESIA
}

\author{
Rini Alfatiyah ${ }^{1}$, Apriyanto2) \\ ${ }^{1)}$ Dosen Teknik Industri, Universitas Pamulang \\ dosen00347@unpam.ac.id
}

\begin{abstract}
ABSTRAK
Perkembangan industri jasa di Indonesia semakin menunjukkan keberadaan dan pertumbuhannya; Industri jasa parkir tidak terkecuali. PT. Securindo Packatama Indonesia adalah perusahaan layanan parkir yang mengatur manajemen parkir di Mall Senayan. Karena jumlah pengunjung sangat besar, terdapat beberapa faktor mempengaruhi tingkat kepuasan pelanggan, yang mempengaruhi kualitas pelayanan yang menurun. Oleh karena itu, untuk mengetahui kepuasan layanan pelayan, survei ini dilakukan untuk menganalisis kepuasan pelanggan dengan layanan parkir di Plaza Senayan Mall menggunakan tiga metode, termasuk Servqual, IPA dan QFD. Penelitian dilakukan dengan sampel 100 responden. Hasil analisis data menggunakan metode Servqual menunjukkan tingkat reliabilitas -0,17, responsiveness -0,068, assurance 0,184, emphaty 0,03, tangibles 0,02, yang berarti secara umum, ada aspek yang tidak memenuhi kepuasan pelanggan. Sedangkan dalam metode IPA, hasil analisis data menunjukkan bahwa ada 6 atribut yang harus ditingkatkan dan dalam metode QFD, hasil analisis data yang diperoleh dari matriks kualitas rumah/House Of Quality (HOQ) menunjukkan penerapan budaya $4 S$ dengan nilai bobot tertinggi. dari 113,13, perencanaan Dalam strategi kepuasan pelanggan, prioritas yang harus diterapkan oleh perusahaan adalah untuk menerapkan budaya 4S (Senyum, Salam, Sapa, Sopan).
\end{abstract}

Kata kunci: Servqual, IPA dan QFD

\section{PENDAhuluan}

Perkembangan dalam suatu perusahaan industri khususnya industri jasa di Indonesia semakin menunjukkan keberadaan dan pertumbuhannya. Industri jasa parkir tidak terkecuali. Contoh aplikasi yang paling umum dalam kehidupan sehari-hari adalah aplikasi program komputer untuk pengelolaan tempat parkir di pusat perbelanjaan, alun-alun, gedung dan hotel. Akhir-akhir ini, hampir setiap mal, alun-alun, gedung, dan hotel di kota ini telah menggunakan aplikasi program komputer untuk mengatur proses parkir.

Plaza Senayan adalah mal yang berlokasi di Senayan, Kebayoran Baru, Jakarta Selatan. Untuk sampai ke mall ini, dapat menggunakan bus Transjakarta dan berhenti di bundaran Senayan. Mall ini memiliki banyak tenant atau toko kelas atas yang menyediakan produk seperti pakaian dan restoran cepat saji. Mall ini juga terkenal di kalangan ekspatriat karena fasilitas dan fasilitasnya yang baik, dan terletak di pusat kota.

Dalam melaksanakan operasional sehari-hari, Plaza Senayan menggunakan aplikasi komputer di parkir kendaraan yang dikendalikan PT. Securindo Packatama Indonesia. Karena jumlah pengunjung sangat sibuk, ada beberapa faktor yang berpengaruh terhadap kepuasan pelanggan, ini mempengaruhi penurunan kualitas layanan yang ditawarkan. Berikut ini adalah keluhan yang sering dikeluhkan pelanggan tentang petugas lapangan pada Tabel 1.

Tabel 1 Keluhan Pelanggan

\begin{tabular}{clc}
\hline No & \multicolumn{1}{c}{ Keluhan } & $\begin{array}{c}\text { Jumlah } \\
\text { (Keluhan } \\
\text { ) }\end{array}$ \\
\hline 1 & $\begin{array}{l}\text { Penginputan nomor } \\
\text { kendaraan lama }\end{array}$ & 4 \\
\hline 2 & Tinta di tiket kurang jelas & 8 \\
\hline 3 & Rambu-rambu tidak jelas & 7 \\
\hline 4 & $\begin{array}{l}\text { Parkir motor untuk } \\
\text { pengunjung kurang luas }\end{array}$ & 28 \\
\hline 5 & Kehilangan helm & 8 \\
\hline 6 & $\begin{array}{l}\text { Antri keluar area parkir } \\
\text { lama }\end{array}$ & 16 \\
\hline 7 & $\begin{array}{l}\text { Tidak tersedia uang } \\
\text { kembalian }\end{array}$ & 17 \\
\hline
\end{tabular}




\begin{tabular}{clc}
\hline 8 & $\begin{array}{l}\text { Tidak ada parkir khusus } \\
\text { motor besar }\end{array}$ & 1 \\
\hline 9 & $\begin{array}{l}\text { Tidak ada ruang tunggu } \\
\text { untuk supir }\end{array}$ & 8 \\
\hline 10 & $\begin{array}{l}\text { Pengaktifan nomor } \\
\text { kendaraan member toko } \\
\text { lama aktif }\end{array}$ & 1 \\
\hline 11 & $\begin{array}{l}\text { Sering time out pada saat } \\
\text { pembayaran non tunai }\end{array}$ & 1 \\
\hline 12 & Pintu keluar motor sedikit & 1 \\
\hline 13 & $\begin{array}{l}\text { Biaya parkir sering tidak } \\
\text { keluar melalui printer }\end{array}$ & 1 \\
\hline 14 & Kendaraan baret & 4 \\
\hline 15 & Printer sering eror & 1 \\
\hline 16 & Pelayanan kurang puas \\
\hline 17 & $\begin{array}{l}\text { Sistem baru supaya lebih } \\
\text { efektif }\end{array}$ & 10 \\
\hline 18 & $\begin{array}{l}\text { Kehilangan barang dalam } \\
\text { kendaraan }\end{array}$ & 2 \\
\hline 19 & $\begin{array}{l}\text { Tidak ada gratis parkir } \\
\text { beberapa menit }\end{array}$ & 3 \\
\hline 20 & $\begin{array}{l}\text { Hanya memiliki 2 jenis } \\
\text { pembayaran non tunai } \\
\text { (Flazz dan E-money) }\end{array}$ & 1 \\
\hline 21 & Biaya parkir mahal \\
\hline 22 & $\begin{array}{l}\text { Pengecekan STNK dirasa } \\
\text { ribet }\end{array}$ & 127 \\
\hline & \multicolumn{1}{c}{ Total } \\
\hline
\end{tabular}

(Sumber: Kuesioner Kepada Petugas Lapangan)

\section{DASAR TEORI}

\section{A. Pengertian Kualitas}

Menurut Tony Wijaya (2018: 09), kualitas adalah sesuatu yang diputuskan oleh pelanggan (Wijaya 2018). Artinya, kualitas didasarkan pada pengalaman pelanggan atau konsumen aktual barang atau jasa yang diukur berdasarkan persyaratan atau atribut tertentu (Wijaya 2018). Sementara itu, menurut Ahmad Khusaini (2016: 06) dalam buku hariannya, mengutip pendapat kualitas Deming, apa pun kebutuhan dan keinginan konsumen (Khusaini, 2016). Ada banyak spesialis lain yang mendefinisikan kualitas.

\section{B. Pengertian Pelayanan}

Menurut Tony Wijaya (2018: 25), kualitas dan layanan mempengaruhi bauran pemasaran dalam banyak hal (Wijaya 2018). Nasution, yang dikutip oleh Ahmad Khusaini dalam buku hariannya (2016: 12), menyatakan bahwa kualitas layanan adalah upaya untuk memenuhi kebutuhan dan keinginan pelanggan, serta menyediakan pengiriman untuk mengimbangi harapan pelanggan (Khusaini, 2016). Reza Dimas Sigit (2014) dalam buku hariannya mengutip pendapat Tjiptono bahwa kualitas layanan didefinisikan sebagai tingkat kelebihan yang diharapkan oleh konsumen dan menjadi indikator dalam pengawasan dalam pemenuhan keinginan pelanggan. (Sigit, 2014).

\section{Pengertian Jasa}

Kata layanan itu sendiri memiliki banyak makna, mulai dari layanan pribadi (layanan pribadi) hingga layanan sebagai produk (Khusaini, 2016). Sejauh ini, banyak pakar pemasaran layanan telah mencoba untuk mendefinisikan pengertian layanan. Menurut Rini Alfatiyah (2018: 37) menyatakan bahwa pelayanan adalah suatu bentuk proses yang terdiri dari kegiatan, tingkat kegunaan atau kepuasan yang di berikan untuk ditawarkan ke konsumen dan tidak berwujud atau berbentuk, tidak menghasilkan dalam kepemilikan sesuatu (Alfatiyah, 2018).

\section{Pelanggan}

Pelanggan adalah seseorang yang memakai atau menggunakan suatu produk berupa barang atau jasa (Khusaini, 2016). Oleh karena itu, dapat diartikan sebagai pelanggan atau kelompok yang menggunakan layanan parkir di Mall Plaza untuk mendapatkan tingkat stres yang lebih baik dan untuk pemenuhan tingkat kepuasan yang diharapkan.

\section{E. Kepuasan Pelanggan}

Menurut Danang Sunyoto yang dikutip oleh Ahmad Khusaini (2016: 25) dalam jurnal, tingkat kepuasan pelanggan adalah suatu tingkat kepuasan yang dirasakan oleh seseorang setelah perbandingan anatar hasil kinerja dan yang dirasakan oleh konsumen (Khusaini, 2016). Tingkat kepuasan merupakan bentuk dari perbedaan antara persepsi (yang dirasakan konsumen) dan ekspektasi (harapan konsumen) (Khusaini, 2016). Pelanggan setelah mempergunakan pelayanan yang rasakan akan merasakan tingkat kepuasan atau merasa tidak puas dalam hal ini pelayanan di bawah harapan, maka pelanggan akan merasa kecewa atas pelayanan yang telah diberikan oleh perusahaan, tetapi kinerja sesuai dengan harapan pelanggan akan terpenuhi dan jika kinerja dapat melebihi harapan, pelanggan akan merasa sangat bahagia bahagia atau sangat senang (Khusaini, 2016). 


\section{F. Uji Validitas dan Uji Reliabilitas}

Uji validitas dan uji reliabilitas dijelaskan di bawah ini:

1. Uji Validitas Sugiyono, dikutip oleh Ahamad Khusaini (2016: 38) dalam jurnalnya, menyatakan bahwa validitas merupakan instrumen yang digunakan dalam mengukur suatu butir kuesioner (Khusaini, 2016).

2. Uji Reliabilitas

Uji reliabilitas digunakan untuk menunjukkan sejauh mana alat ukur (instrumen) dapat menunjukkan stabilitas, keteguhan atau stabilitas hasil pengamatan ketika diukur dengan instrumen dalam penelitian selanjutnya dengan kondisi tetap. Instrumen ini dianggap andal jika mampu mengungkapkan data yang dapat dipercaya dan sesuai dengan fakta aktual atau hasil penelitian>0,6.

\section{G. Metode Service Quality (Servqual)}

Dalam penelitian ini menggunakan metode service quality (Sevqual) merupakan metode dalam mengukur kualitas dalam sering digunakan di dalam penelitian kualitas pelayanan secara luas (Dharmawan 2014).

Ahmad Khusaini (2016: 21) mengutip pendapat Parasuraman, antara lain sebagai berikut (Khusaini, 2016):

\section{Daya Tanggap (Responsiveness)}

Setiap karyawan dalam memberikan bentuk layanan memprioritaskan aspek layanan yang sangat mempengaruhi perilaku orang yang menerima layanan, sehingga daya tanggap karyawan diperlukan untuk melayani pelanggan sesuai dengan tingkat penyerapan, pemahaman, dan ketidaksesuaian mereka. berbagai bentuk layanan yang tidak diketahuinya.

2. Jaminan (Assurance)

Setiap bentuk layanan membutuhkan kepastian layanan yang diberikan. Kepastian suatu layanan sangat ditentukan oleh jaminan karyawan yang menyediakan layanan tersebut, sehingga orang yang menerima layanan lebih puas dan percaya diri bahwa semua bentuk layanan yang diberikan akan diselesaikan dan diselesaikan dengan cepat, akurasi, kenyamanan, kelancaran dan kualitas layanan.

3. Bukti Fisik (Tangibility)

Memahami bukti fisik tentang kualitas layanan adalah bentuk pembaruan fisik aktual yang dapat dilihat atau digunakan oleh karyawan sesuai dengan penggunaan dan pemanfaatannya yang dapat dirasakan untuk membantu layanan yang diterima oleh orang yang menginginkan layanan sehingga mereka puas dengan hal itu. Layanan yang dirasakan, yang juga menunjukkan kinerja pekerjaan dalam menyediakan layanan.

4. Empati (Empathy)

Setiap kegiatan layanan atau aktivitas pelayanan membutuhkan pemahaman dan pengertian tentang penyatuan asumsi atau kepentingan dalam masalah terkait layanan. Layanan akan bekerja dengan lancar dan berkualitas jika semua pihak yang terlibat dalam layanan memiliki empati (empati) untuk menyelesaikan atau mengelola atau memiliki komitmen yang sama terhadap layanan.

5. Kendalan (Reliability)

Setiap layanan membutuhkan bentuk layanan yang andal, yang berarti bahwa dalam memberikan layanan, semua karyawan diharapkan memiliki pengetahuan, pengalaman, kemandirian, penguasaan dan profesionalisme yang tinggi di tempat kerja sehingga aktivitas kerja yang dilakukan menghasilkan bentuk layanan yang memuaskan tanpa keluhan dan kesan. layanan berlebihan yang diterima oleh masyarakat.

Tahapan yang dipergunakan dalam analisis kesenjangan atau gap, terdapat beberapa hal yang perlu dipertimbangkan, antara lain (Dharmawan 2014):

1. Kesenjangan atau gap negatif berarti pelayanan yang diberikan tidak memenuhi harapan pelanggan, sehingga perlu diadakan peningkatan kualitas diperlukan;

2. Kesenjangan atau gap nol berarti pelayanan yang diberikan sesuai dengan harapan pelanggan;

3. Kesenjangan atau gap positif berarti pelayanan yang diberikan melebihi harapan pelanggan.

\section{H. Importance Performance Analysis (IPA)}

Importance Performance Analysis

(IPA) merupakan suatu metode yang dipergunakan dalam menggambarkan tingkat persepsi atau tingkat kepuasan yang dirasakan oleh pelanggan. Metode IPA pertama kali diperkenalkan oleh John A. Martilla dan John C. James pada tahun 1977, metode ini berguna dalam mengkukur korelasi atau hubungan antara apa yang dirasakan oleh konsumen (persepsi) dan prioritas untuk meningkatkan 
kualitas suatu produk/pelayanan yang dipergunakan dalam sebagai analisis kuadran (Dharmawan 2014).

Importance Performance Analysis (IPA) dipergunakan dalam mengukur tingkat kepuasan pelanggan dengan kinerja pihak lain. Kepuasan seseorang diukur dengan membandingkan tingkat harapan dengan kinerja pihak lain. IPA sering digunakan oleh perusahaan untuk mengukur tingkat kepuasan pelanggan. Perusahaan membandingkan harapan konsumen dengan kinerja. Jika tingkat harapan lebih tinggi dari kinerja perusahaan, itu berarti konsumen belum mencapai kepuasan dan sebaliknya.

Quality Function Deployment (QFD)

Metode Quality Function Deployment

(QFD) merupakan metode yang berfungsi untuk membuat skala prioritas dalam kebutuhan atau keinginan pelanggan untuk menetapkan standar layanan. Tony Wijaya telah menyatakan bahwa QFD meruoakan metode yang berfungsi dalam mendukung dan menerapkan filosofi (Wijaya 2018).

Dalam pembuatan matriks House of Quality (HOQ) mempunyai enam komponen yang utama, yang dijelaskan sebagai berikut:

1. Voice of Customer (VOC), daftar dari suara konsumen dari kebutuhan dan keinginan pelanggan. Pada VOC ini diperoleh dengan membagikan kuesioner kepada klien dengan metode. SERVQUAL.

2. Technical Response, daftar tanggapan manajemen yang relevan dengan hasil voice of customer. Bagian ini dibuat oleh manajemen tentang tanggapan apa yang dapat diterapkan untuk memenuhi kebutuhan pelanggan..

3. Relationship Matrix, Matriks ini menggambarkan persepsi tim QFD tentang hubungan antara VOC dan respons teknis. Skala yang sering digunakan dalam matriks ini di jelaskan dengan simbol-simbol berikut:
a. Sembilan (9) artinya simbol yang melambangkan hubungan yang kuat;
b. Tiga (3) artinya simbol yang melambangkan hubungan yang sedang;
c. Satu (1) artinya simbol yang melambangkan hubungan yang lemah.

4. Planning Matrix, matriks menggambarkan apa yang dirasakan oleh pelanggan dalam VOC. Di mana itu berisi importance to customer, improvement ratio, sales point, target value, raw weght, dan normalized raw weight.
5. Korelasi teknis (technical correlation), digunakan dalam mengidentifikasi pengaruh antara masing-masing tanggapan teknis, mendukung atau tidak mendukung satu sama lain.

6. Matriks teknis (technical matrix), berisi tujuan yang akan dicapai untuk setiap respons teknis. Matriks ini dilakukan oleh manajemen yang lebih memahami kemampuan perusahaan untuk mencapai tujuannya.

\section{Pengisian Matriks House of Quality (HOQ)}

Sebelum menyelesaikan matrik House of Quality, perlu membuat matriks perencaan yang disusun oleh (Dharmawan 2014):

1. Penyusuna Customer Requiretment (Whats) Matriks didapat berdasarkan hasil kuesioner dari pelanggan Mall Plaza Senayan.

2. Technical Descriptor (Hows)

Merupakan respons atau rekayasa untuk meningkatkan kepuasan pelanggan Mall Plaza Senayan.

3. Hubungan Antara Customer Requiretment dan Technical Descriptor

Matriks ini digunakan untuk melihat hubungan sebab akibat antara kebutuhan dan persyaratan pelanggan dengan deskriptor teknis.

4. Tingkat Kepentingan Konsumen (Importance to Costumer)

Tingkat kepuasan pelanggan sangat penting untuk digunakan untuk menentukan kebutuhan konsumen.

5. Nilai Target (Target Value)

Nilai Target ditentukan melalui diskusi oleh guru dan komite sekolah. Dalam menentukan Nilai Target, skala peringkat mengacu pada pentingnya nilai Pelanggan. Skala peringkat sasaran ditunjukkan pada Tabel 2.

Tabel 2 Skala Target Value

\begin{tabular}{ll}
\hline \multicolumn{1}{c}{ Skala } & \multicolumn{1}{c}{ Keterangan } \\
\hline $1,00-1,99$ & Sangat Tidak Puas \\
\hline $2,00-2,99$ & Tidak Puas \\
\hline $3,00-3,99$ & Puas \\
\hline $4,00-4,99$ & Sangat Puas \\
\hline 5,00 & Sangat Puas Sekali \\
\hline
\end{tabular}

6. Tingkat Peningkatan (Improvement Ratio) Tingkat peningkatan digunakan untuk menunjukkan jumlah perubahan atau perbaikan yang harus dilakukan. Untuk menemukan formula Tingkat Peningkatan sebagai berikut 
$\therefore \mathrm{IR}=\frac{\text { Target Value }}{\text { Kepuasan }}$

Arti nilai Improvement Ratio dapat dilihat pada Tabel 3.

Tabel 3 Improvement Ratio

\begin{tabular}{cl}
\hline Nilai & \multicolumn{1}{c}{ Keterangan } \\
\hline 1 & Tidak ada sales point \\
\hline 1,2 & Sales point sedang \\
\hline 1,5 & Sales point kuat \\
\hline
\end{tabular}

7. Raw Weight and Normalized Raw Weight Digunakan untuk menunjukkan jumlah peningkatan dalam kriteria kebutuhan pelanggan. Dalam bentuk matematika penentuan nilai Raw Weight and Normalized Raw Weight dengan rumus sebagai berikut: Raw Weight = Importance to customer $\mathrm{x}$ Improvement Ratio x Sales Point Normalized Raw Weight $=$ Raw Weight : Raw Weight Total

\section{METODOLOGI PENELITIAN}

\section{A. Lokasi Penelitian}

Berdasarkan penelitian yang dilakukan, lokasi penelitian dibatasi berdasarkan lokasi dan objek penelitian, sebagai berikut:

1. Tempat Penelitian

Penelitian ini di laksanakan di PT. Securindo Packatama Indonesia terletak di Jl. Asia Afrika No. 08, Gelora, Tanah Abang Jakarta Pusat.

2. Waktu Penelitian

Penelitian dilakukan dari pada bulan April 2018 sampai Oktober 2018.

\section{B. Jenis Penelitian}

Dalam penelitian ini, metode yang digunakan adalah Metode Deskriptif yang menggambarkan data aktual yang dianalisis untuk menguji asumsi yang dibuat dan menganalisis situasi dan mengumpulkan beberapa data berdasarkan fakta perusahaan.

\section{Data dan Sumber Data}

Berikut data dan sumber data yang di lakukan oleh peneliti di PT. Securindo Packatama Indonesia:

1. Data

a. Data Kualitatif

Merupakan kumpulkan data perusahaan pada saat pengambilan data dan data yang telah terjadi atau masa lalu untuk melihat perkembangan perusahaan.

b. Data Kuantitatif
Merupakan pengolahan data dalam perhitungan, di mana data disajikan dalam bentuk angka.

2. Sumber Data

\section{a. Data Primer}

Merupakan kumpulan data yang di peroleh secara langsung dari perusahaan yang diteliti dalam pengamatan dan dicatat untuk diproses lebih lanjut,

b. Data Sekunder

Sumber data dari perusahaan kemudian di oleh atau diproses oleh peneliti.

\section{Teknik Pengumpulan Data}

Pada tahap teknik pengumpulan data dalam penelitian ini dijelaskan sebagai berikut:

1. Observasi

Teknik pengumpulan data dengan cara turun langsung ke lapangan, untuk mendapatkan data aktual yang dibutuhkan dalam penelitian ini.

2. Wawancara

Dibuat langsung dengan pelanggan PT. Securindo Packatama Indonesia berbelanja di Plaza Senayan Mall.

3. Dokumentasi

Data diperoleh dari dokumen perusahaan, catatan atau catatan yang dibutuhkan oleh para peneliti di lokasi penelitian.

\section{HASIL DAN PEMBAHASAN}

\section{A. Gambaran Umu Perusahaan}

PT. Securindo Packatama Indonesia (Secure Parking) merupakan suatu perusahaan yang bergerak dalam bidang perkantoran, pusat pembelanjaan menggunakan jasa secure parking.Salah satu objek penelitian yang dilakukan peneliti berada di Mall Senayan yang beralamat di Jalan Asia Afrika No. 8 Jakarta Selatan.

\section{B. Pembahasan}

Pada pembahasan ini diperoleh tingkat kepuasan konsumen seperti Tabel 3.

Tabel 3 Tingkat Kepuasan

\begin{tabular}{llccc}
\hline No & $\begin{array}{c}\text { Pertany } \\
\text { aan }\end{array}$ & $\begin{array}{c}\text { Perseps } \\
\text { i }\end{array}$ & $\begin{array}{c}\text { Tingk } \\
\text { at } \\
\text { Ekspe } \\
\text { ktasi }\end{array}$ & $\begin{array}{c}\text { Ting } \\
\text { kat } \\
\text { Kepe } \\
\text { nting } \\
\text { an }\end{array}$ \\
\hline \multicolumn{4}{c}{ Keandalan (Reliability) } \\
\hline P1 & $\begin{array}{l}\text { Kecepa } \\
\text { tan } \\
\text { dalam }\end{array}$ & 3,79 & 4,16 & 4,38 \\
\hline
\end{tabular}




\begin{tabular}{|c|c|c|c|c|}
\hline No & $\begin{array}{c}\text { Pertany } \\
\text { aan }\end{array}$ & $\begin{array}{l}\text { Tingkat } \\
\text { Perseps } \\
\quad \text { i }\end{array}$ & $\begin{array}{l}\text { Tingk } \\
\text { at } \\
\text { Ekspe } \\
\text { ktasi }\end{array}$ & $\begin{array}{c}\text { Ting } \\
\text { kat } \\
\text { Kepe } \\
\text { nting } \\
\text { an } \\
\end{array}$ \\
\hline & $\begin{array}{l}\text { pelaya } \\
\text { nan dan } \\
\text { penyajia } \\
\text { n }\end{array}$ & & & \\
\hline $\mathrm{P} 2$ & $\begin{array}{l}\text { Kemuda } \\
\text { han } \\
\text { pembaya } \\
\text { ran } \\
\text { (tunai } \\
\text { dan non } \\
\text { tunai) }\end{array}$ & 4,03 & 4,65 & 3,68 \\
\hline P3 & $\begin{array}{l}\text { Kualitas } \\
\text { pekerjaa } \\
\text { n }\end{array}$ & 4,15 & 4,06 & 3,82 \\
\hline $\mathrm{P} 4$ & $\begin{array}{l}\text { Keakura } \\
\text { tan } \\
\text { informas } \\
\text { i yang di } \\
\text { berikan } \\
\text { petugas }\end{array}$ & 3,79 & 3,75 & 3,79 \\
\hline P5 & $\begin{array}{l}\text { Kesiapa } \\
\mathrm{n} \text { tim } \\
\text { pada } \\
\text { saat } \\
\text { terjadi } \\
\text { tambaha } \\
\mathrm{n} \text { antrian } \\
\text { panjang }\end{array}$ & 4,01 & 4,00 & 4,13 \\
\hline & \multicolumn{4}{|c|}{ Daya Tanggap (Responsiveness) } \\
\hline P6 & $\begin{array}{l}\text { Kesaba } \\
\text { ran dan } \\
\text { ketelaten } \\
\text { an } \\
\text { karyawa } \\
\text { n dalam } \\
\text { melayan } \\
\text { i pelang } \\
\text { gan }\end{array}$ & 4,08 & 4,47 & 4,40 \\
\hline $\mathrm{P} 7$ & $\begin{array}{l}\text { Mampu } \\
\text { merespo } \\
\mathrm{n} \\
\text { keluhan } \\
\text { dan } \\
\text { persoala } \\
\mathrm{n}\end{array}$ & 4,18 & 4,28 & 3,65 \\
\hline P8 & $\begin{array}{l}\text { Pemberi } \\
\text { an } \\
\text { informas } \\
\text { i yang } \\
\text { jelas } \\
\text { kepada }\end{array}$ & 4,40 & 4,14 & 4,19 \\
\hline
\end{tabular}

\begin{tabular}{|c|c|c|c|c|}
\hline No & $\begin{array}{c}\text { Pertany } \\
\text { aan }\end{array}$ & $\begin{array}{c}\text { Tingkat } \\
\text { Perseps } \\
\quad \text { i }\end{array}$ & $\begin{array}{c}\text { Tingk } \\
\text { at } \\
\text { Ekspe } \\
\text { ktasi }\end{array}$ & $\begin{array}{c}\text { Ting } \\
\text { kat } \\
\text { Kepe } \\
\text { nting } \\
\text { an }\end{array}$ \\
\hline & $\begin{array}{l}\text { pelang } \\
\text { gan }\end{array}$ & & & \\
\hline P9 & $\begin{array}{l}\text { Petugas } \\
\text { cepat } \\
\text { tanggap } \\
\text { menanga } \\
\text { ni } \\
\text { masalah }\end{array}$ & 4,24 & 4,18 & 3,76 \\
\hline $\begin{array}{c}\mathrm{P} 1 \\
0\end{array}$ & $\begin{array}{l}\text { Memenu } \\
\text { hi } \\
\text { perminta } \\
\text { an } \\
\text { khusus } \\
\text { dari } \\
\text { pelang } \\
\text { gan }\end{array}$ & 4,11 & 4,13 & 4,29 \\
\hline \multicolumn{5}{|c|}{ Jaminan (Assurance) } \\
\hline $\begin{array}{c}\mathrm{P} 1 \\
1\end{array}$ & $\begin{array}{l}\text { Tidak } \\
\text { ada } \\
\text { kekeliru } \\
\text { an pada } \\
\text { saat } \\
\text { proses } \\
\text { pembaya } \\
\text { ran }\end{array}$ & 4,02 & 3,82 & 3,80 \\
\hline $\begin{array}{c}\mathrm{P} 1 \\
2\end{array}$ & $\begin{array}{l}\text { Petugas } \\
\text { bersifat } \\
\text { sopan } \\
\text { dan } \\
\text { ramah } \\
\text { kepada } \\
\text { pelang } \\
\text { gan }\end{array}$ & 4,06 & 4,06 & 4,05 \\
\hline $\begin{array}{c}\mathrm{P} 1 \\
3\end{array}$ & $\begin{array}{l}\text { Jaminan } \\
\text { keama } \\
\text { nan dan } \\
\text { kenyama } \\
\text { nan }\end{array}$ & 3,92 & 4,16 & 3,79 \\
\hline $\begin{array}{c}\mathrm{P} 1 \\
4\end{array}$ & $\begin{array}{l}\text { Kemam } \\
\text { puan } \\
\text { petugas } \\
\text { dalam } \\
\text { menan } \\
\text { gani } \\
\text { masalah } \\
\end{array}$ & 4,26 & 3,89 & 4,17 \\
\hline $\begin{array}{c}\mathrm{P} 1 \\
5\end{array}$ & $\begin{array}{l}\text { Pekerjaa } \\
\text { n sesuai } \\
\text { standar } \\
\text { SOP }\end{array}$ & 4,19 & 3,69 & 3,74 \\
\hline & $\mathrm{En}$ & $\operatorname{ti}\left(E m_{l}\right.$ & & \\
\hline
\end{tabular}




\begin{tabular}{|c|c|c|c|c|}
\hline No & $\begin{array}{c}\text { Pertany } \\
\text { aan }\end{array}$ & $\begin{array}{c}\text { Tingkat } \\
\text { Perseps } \\
\quad \text { i }\end{array}$ & $\begin{array}{c}\text { Tingk } \\
\text { at } \\
\text { Ekspe } \\
\text { ktasi }\end{array}$ & $\begin{array}{c}\text { Ting } \\
\text { kat } \\
\text { Kepe } \\
\text { nting } \\
\text { an }\end{array}$ \\
\hline $\begin{array}{c}\mathrm{P} 1 \\
6\end{array}$ & $\begin{array}{l}\text { Karya } \\
\text { wan } \\
\text { menden } \\
\text { garkan } \\
\text { dan } \\
\text { menerim } \\
\text { a } \\
\text { keluhan } \\
\text { konsu } \\
\text { men }\end{array}$ & 4,29 & 4,11 & 3,37 \\
\hline $\begin{array}{c}\mathrm{P} 1 \\
7\end{array}$ & $\begin{array}{l}\text { Pelaya } \\
\text { nan yang } \\
\text { adil } \\
\text { tanpa } \\
\text { meman } \\
\text { dang } \\
\text { status }\end{array}$ & 4,16 & 4,24 & 3,41 \\
\hline $\begin{array}{c}\mathrm{P} 1 \\
8\end{array}$ & $\begin{array}{l}\text { Mampu } \\
\text { memenu } \\
\text { hi } \\
\text { keingina } \\
\text { n pelang } \\
\text { gan }\end{array}$ & 4,21 & 4,02 & 3,48 \\
\hline $\begin{array}{c}\mathrm{P} 1 \\
9\end{array}$ & $\begin{array}{l}\text { Member } \\
\text { ikan } \\
\text { perhatia } \\
\text { n khusus } \\
\text { kepada } \\
\text { pelang } \\
\text { gan }\end{array}$ & 4,05 & 4,13 & 4,12 \\
\hline $\begin{array}{c}\mathrm{P} 2 \\
0\end{array}$ & $\begin{array}{l}\text { Pelaya } \\
\text { nan yang } \\
\text { ramah } \\
\text { terhadap } \\
\text { pelang } \\
\text { gan }\end{array}$ & 4,18 & 4,74 & 4,02 \\
\hline \multicolumn{5}{|c|}{ Bukti Langsung (Tangibles) } \\
\hline $\begin{array}{c}\mathrm{P} 2 \\
1\end{array}$ & $\begin{array}{l}\text { Penampi } \\
\text { lan } \\
\text { petugas }\end{array}$ & 4,00 & 4,00 & 4,09 \\
\hline $\begin{array}{c}\mathrm{P} 2 \\
2\end{array}$ & $\begin{array}{l}\text { Rambu- } \\
\text { rambu } \\
\text { yang } \\
\text { jelas }\end{array}$ & 4,11 & 4,03 & 3,84 \\
\hline $\begin{array}{c}\mathrm{P} 2 \\
3\end{array}$ & $\begin{array}{l}\text { Area } \\
\text { parkir } \\
\text { bersih }\end{array}$ & 4,18 & 4,23 & 3,90 \\
\hline $\begin{array}{c}\mathrm{P} 2 \\
4\end{array}$ & $\begin{array}{l}\text { Menyedi } \\
\text { akan } \\
\text { parkir } \\
\text { khusus }\end{array}$ & 4,11 & 4,22 & 3,74 \\
\hline
\end{tabular}

\begin{tabular}{ccccc}
\hline No & $\begin{array}{c}\text { Pertany } \\
\text { aan }\end{array}$ & $\begin{array}{c}\text { Tingkat } \\
\text { Perseps } \\
\text { i }\end{array}$ & $\begin{array}{c}\text { Tingk } \\
\text { at } \\
\text { Ekspe } \\
\text { ktasi }\end{array}$ & $\begin{array}{c}\text { Ting } \\
\text { kat } \\
\text { Kepe } \\
\text { nting } \\
\text { an }\end{array}$ \\
\hline $\begin{array}{c}\text { P2 } \\
5\end{array}$ & $\begin{array}{l}\text { Kebersih } \\
\text { an toilet }\end{array}$ & 4,05 & 3,87 & 4,38 \\
\hline
\end{tabular}

\section{Analisis Servqual}

Pada konsep Servqual dalam menganalisa kualitas pelayanan dilakukan dengan cara menghitunga gap (kesenjangan) antara persepsi atau yang dirasakan oleh konsumen dan harapan atau ekspektasi dari pelanggan. Untuk mencari gap (kesenjangan) kelima dimensi kualitas digunakan rumus sebagai berikut:

$$
\mathrm{Q}=\mathrm{P}-\mathrm{E}
$$

Hasil analisis ditas dapat dilihat pada Tabel 4.

Tabel 4 Kesenjangan (Gap)

\begin{tabular}{|c|c|c|c|c|}
\hline \multirow{2}{*}{\multicolumn{2}{|c|}{ Pernyataan }} & \multicolumn{3}{|c|}{ Customer Satisfaction } \\
\hline & & $\begin{array}{c}\text { Persep } \\
\text { si }\end{array}$ & $\begin{array}{l}\text { Ekspe } \\
\text { ktasi }\end{array}$ & Gap \\
\hline \multicolumn{5}{|c|}{ Reliability (Keandalan) } \\
\hline & $\begin{array}{l}\text { Kecepatan } \\
\text { dalam } \\
\text { pelayanan } \\
\text { dan } \\
\text { penyajian }\end{array}$ & 3,79 & 4,16 & $-0,37$ \\
\hline $\begin{array}{l}\mathrm{P} \\
2\end{array}$ & $\begin{array}{l}\text { Kemudahan } \\
\text { pembayaran } \\
\text { (tunai dan } \\
\text { non tunai) }\end{array}$ & 4,03 & 4,65 & $-0,62$ \\
\hline $\begin{array}{l}\mathrm{P} \\
3\end{array}$ & $\begin{array}{l}\text { Kualitas } \\
\text { pekerjaan }\end{array}$ & 4,15 & 4,06 & 0,09 \\
\hline $\begin{array}{l}\mathrm{P} \\
4\end{array}$ & $\begin{array}{l}\text { Keakuratan } \\
\text { informasi } \\
\text { yang di } \\
\text { berikan } \\
\text { petugas }\end{array}$ & 3,79 & 3,75 & 0,04 \\
\hline $\begin{array}{l}\mathrm{P} \\
5\end{array}$ & $\begin{array}{l}\text { Kesiapan } \\
\text { petugas } \\
\text { tambahan } \\
\text { pada saat } \\
\text { terjadi } \\
\text { antrian yang } \\
\text { sangat } \\
\text { panjang. }\end{array}$ & 4,01 & 4,00 & 0,01 \\
\hline \multicolumn{5}{|c|}{ Reponsiveness (Daya Tanggap) } \\
\hline 6 & $\begin{array}{l}\text { Kesabaran } \\
\text { dan } \\
\text { ketelatenan }\end{array}$ & 4,08 & 4,47 & $-0,39$ \\
\hline
\end{tabular}




\begin{tabular}{|c|c|c|c|c|}
\hline \multirow{2}{*}{\multicolumn{2}{|c|}{ Pernyataan }} & \multicolumn{3}{|c|}{ Customer Satisfaction } \\
\hline & & $\begin{array}{c}\text { Persep } \\
\text { si }\end{array}$ & $\begin{array}{c}\text { Ekspe } \\
\text { ktasi }\end{array}$ & Gap \\
\hline & $\begin{array}{l}\text { karyawan } \\
\text { dalam } \\
\text { melayani } \\
\text { pelanggan } \\
\end{array}$ & & & \\
\hline $\begin{array}{l}P \\
7\end{array}$ & $\begin{array}{l}\text { Mampu } \\
\text { merespon } \\
\text { keluhan dan } \\
\text { persoalan }\end{array}$ & 4,03 & 4,28 & $-0,25$ \\
\hline $\begin{array}{l}\mathrm{P} \\
8\end{array}$ & $\begin{array}{l}\text { Pemberian } \\
\text { informasi } \\
\text { yang jelas } \\
\text { kepada } \\
\text { pelanggan }\end{array}$ & 4,40 & 4,14 & 0,26 \\
\hline $\begin{array}{l}P \\
9\end{array}$ & $\begin{array}{l}\text { Petugas } \\
\text { cepat } \\
\text { tanggap } \\
\text { menangani } \\
\text { masalah } \\
\end{array}$ & 4,24 & 4,18 & 0,06 \\
\hline $\begin{array}{l}\mathrm{P} \\
1 \\
0\end{array}$ & $\begin{array}{l}\text { Memenuhi } \\
\text { permintaan } \\
\text { khusus dari } \\
\text { pelanggan }\end{array}$ & 4,11 & 4,13 & $-0,02$ \\
\hline \multicolumn{5}{|c|}{ Assurance (Jaminan) } \\
\hline $\begin{array}{l}\mathrm{P} \\
1 \\
1\end{array}$ & $\begin{array}{l}\text { Tidak ada } \\
\text { kekeliruan } \\
\text { pada saat } \\
\text { proses } \\
\text { pembayaran }\end{array}$ & 4,02 & 3,82 & 0,2 \\
\hline $\begin{array}{l}\mathrm{P} \\
1 \\
2\end{array}$ & $\begin{array}{l}\text { Petugas } \\
\text { bersifat } \\
\text { sopan dan } \\
\text { ramah } \\
\text { kepada } \\
\text { pelanggan }\end{array}$ & 4,06 & 4,06 & 0 \\
\hline $\begin{array}{l}\mathrm{P} \\
1 \\
3\end{array}$ & $\begin{array}{l}\text { Jaminan } \\
\text { keamanan } \\
\text { dan } \\
\text { kenyamanan }\end{array}$ & 3,92 & 4,16 & $-0,24$ \\
\hline $\begin{array}{l}\mathrm{P} \\
1 \\
4\end{array}$ & $\begin{array}{l}\text { Kemampuan } \\
\text { petugas } \\
\text { dalam } \\
\text { menangani } \\
\text { masalah } \\
\end{array}$ & 4,26 & 3,89 & 0,37 \\
\hline $\begin{array}{l}\mathrm{P} \\
1 \\
5\end{array}$ & $\begin{array}{l}\text { Pekerjaan } \\
\text { sesuai } \\
\text { standar SOP }\end{array}$ & 4,19 & 3,69 & 0,59 \\
\hline \multicolumn{5}{|c|}{ Emphaty (Perhatian) } \\
\hline $\begin{array}{l}P \\
1 \\
6\end{array}$ & $\begin{array}{l}\text { Karyawan } \\
\text { mendengarka } \\
\mathrm{n} \text { dan } \\
\text { menerima }\end{array}$ & 4,29 & 4,11 & 0,18 \\
\hline
\end{tabular}

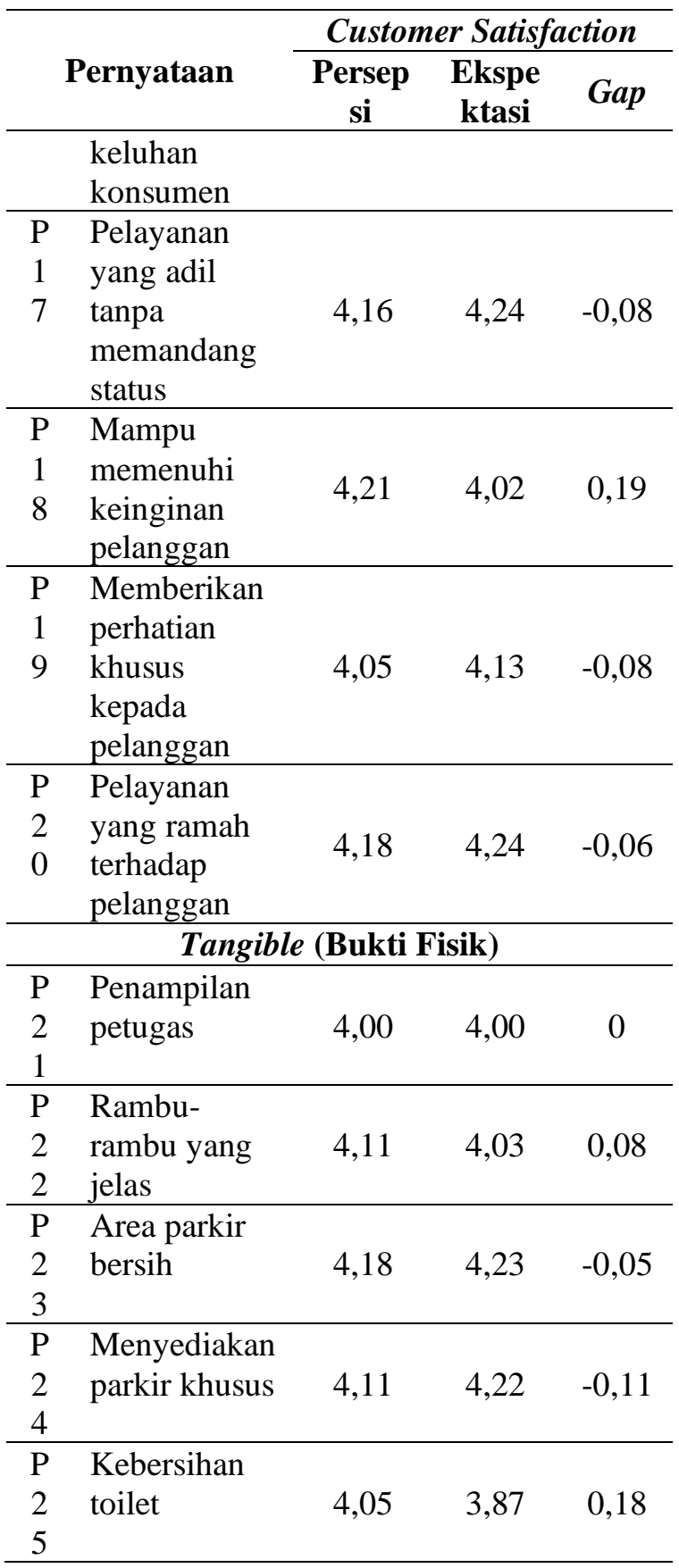

Setelah dilakukan analisis Serqual diperoleh 3 dimensi yang nilai gapnya positif yang artinya jasa yang diberikan perusahaan sudah memenuhi keinginan pelanggan, 3 dimensi tersebut adalah Assurance (Jaminan) sebesar 0,18, Emphaty (Perhatian) sebesar 0,03, Tangible (Bukti Fisik) sebesar 0,02. Namun perusahaan tidak boleh mengabaikan 2 dimensi yang bernilai negative, 2 dimensi tersebut adalah Reliability (Keandalan) sebesar -0,17, Reponsiveness (Daya Tanggap) sebesar -0,07.

\section{Analisis IPA}

Sebelum perhitungan dari Servqual ke QFD, terlebih dahulu perhitungan dengan 
Importance Performance Analysis (IPA) digunakan untuk mendapatkan faktor-faktor yang mempengaruhi hasil yang diperoleh dalam dimensi SERVQUAL. Dari 25 atribut pertanyaan yang diperoleh dari gfrafik IPA pada Gambar 1:

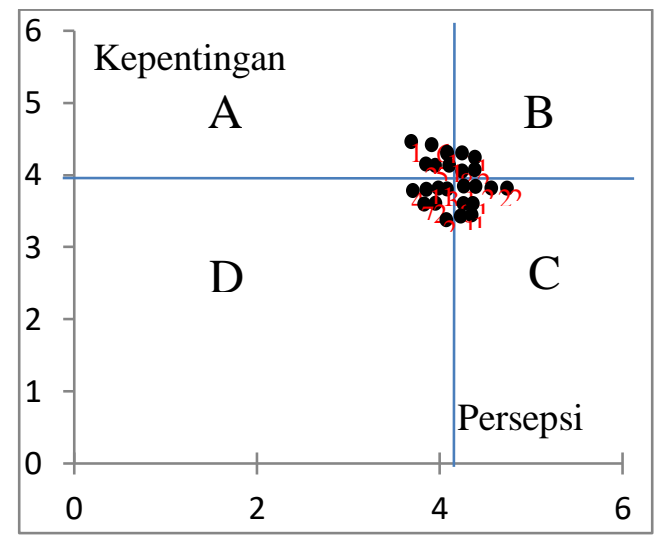

(Sumber: Pengolahan Sendiri)

Gambar 1 Grafik Kartesius

Keterangan:

a. Kuadran A menunjjukkan bahwa terdapat faktor atau atribut yang mempengaruhi kepuasan pelanggan, termasuk elemen layanan yang dianggap sangat penting, tetapi manajemen belum mengimplementasikannya sesuai dengan keinginan pelanggan, sehingga kecewa/tidak puas. Atribut yang termasuk dalam kuadran ini adalah atribut P1, P5, P6, P12, P19, dan P21.

b. Kuadran B menunjukkan elemen dasar layanan yang telah berhasil diimplementasikan. Atribut yang termasuk dalam kuadran ini adalah atribut P8, P10, P14, dan P20.

c. Kuadaran C, Menunjukkan faktor-faktor yang mempengaruhi pelanggan kurang penting, tetapi implementasi berlebihan. Dianggap kurang penting tetapi sangat bermanfaat. Atribut yang termasuk dalam kuadran ini adalah atribut $\mathrm{P} 9, \mathrm{P} 15$, P16, P17, P18, P22, P23, dan P24.

d. Kuadran D menunjukkan beberapa faktor yang memiliki pengaruh paling kecil terhadap pelanggan. Implementasinya oleh perusahaan biasa-biasa saja. Dianggap kurang penting dan kurang memuaskan. Atribut yang termasuk dalam kuadran ini adalah atribut P2, P3, P4, P7, P11, P13, dan P25.
Sebagian besar atribut ditemukan di Kuadran C dengan hingga 8 atribut. Dapat disimpulkan bahwa layanan parkir di PT. Securindo Packatama Indonesia telah memenuhi kepuasan pelanggan, tetapi perusahaan tidak boleh mengabaikan 6 atribut yang ada di kuadran A. Ini karena atribut yang ada di kuadran A, pelayanan yang diberikan oleh suatu perusahaan yang tidak memenuhi ekspeksi pelanggan.

\section{E. Analisis QFD}

Setelah dianalisis dengan metode IPA, dilanjutkan dengan analisa Quality Function Deployment (QFD) bahwa kebutuhan pelanggan meliputi kecepatan dalam layanan dan presentasi, kesiapan staf tambahan dalam antrean panjang, kesabaran dan kesabaran staf dalam melayani pelanggan, staf sopan dan ramah kepada pelanggan, menyediakan Perhatian khusus kepada pelanggan, tampaknya resmi.

\section{KESIMPULAN DAN SARAN}

\section{A. Kesimpulan}

Kesimpulan dalam penelitian ini adalah sebagai berikut:

1. Kualitas jasa pelayanan parkir di PT. Securindo Packatama Indonesia area Mall Plaza Senayan adalah belum memenuhi kepuasan pelanggan hal karena dimensi Reliability (Keandalan) bernilai $-0,17$ dan Reponsiveness (Daya Tanggap) bernilai 0,07 .

2. Berdasarkan hasil dari analisis dengan metode Servqual, IPA dan QFD perencanaan yang akan direncanakan adalah sebagai berikut:

a. Menerapkan budaya 4S ( Senyum, Sapa, Salam, Sopan) dengan nilai bobot perhitungan 113,13.

b. Memberikan reward kepada petugas dengan nilai bobot perhitungan 112,68.

c. Bersikap personal dengan nilai bobot perhitungan 51,69.

d. Layani pelanggan dengan nilai bobot perhitungan 37,71.

e. Melakukan evaluasi secara berkala dengan nilai bobot perhitungan 37,17.

f. Kualitas pelayanan yang ramah dengan nilai bobot perhitungan 12,37.

\section{B. Saran}

Dari kesimpulan diatas maka saran yang sebaiknya perlu dilakukan oleh PT. 
Securindo Packatama Indonesia adalah sebagai berikut:

1. Perusahaan tidak boleh mengabaikan 2 dimensi yang bernilai negatif hal ini karena akan mempengaruhi tingkat kepuasan konsumen yang berimbas pada menurunnya kualitas jasa yang ditawarkan;

2. Berdasarkan hasil analisa prioritas utama yang harus dilakukan pertama kali oleh PT. Securindo Packatama Indonesia lokasi Mall Plaza Senayan adalah yang bernilai bobot paling tinggi yaitu menerapkan budaya $4 \mathrm{~S}$ (Senyum, Salam, Sapa, Sopan) karena memiliki bobot tertinggi sebesar 113,13;

3. Saran bagi peneliti selanjutnya adalah dengan melakukan penelitian tentang menganalisis hubungan antara tingkat kepuasan pelanggan, dengan mempertimbangkan karakter masingmasing pelanggan yang berbeda.

\section{DAFTAR PUSTAKA}

Abidin, N. (2015). Analisa Pengaruh Kualitas Pelayanan dan Harga Terhadap Kepuasan Pelanggan. Surakarta.

Alfatiyah, R. (2018). Perancangan Industri Jasa. Tangerang.

Anggraeni, D. P., Kumadji, S., \& Sunarti. (2016). Pengaruh Kualitas Produk Terhadap Kepuasan dan Loyalitas Pelanggan. Malang.

Dharmawan, A. (2014). Rancangan Perbaikan Kualitas Pelayanan Jasa Dengan Metode Servqual, Importance Performance Analysis, dan Quality Function Deployment Pada Plasa Telkom. Surabaya.

Dharmawan, A. (2014). Rancangan Perbaikan Kualitas PelayananJasa dengan Metode Serviqual, IPA dan QFD. Surabaya.

Khusaini, A. (2016). Analisis Kualitas Pelayanan Terhadap Kepuasan Konsumen Di SPA Club Arena. Yogyakarta.

Panjaitan, J. E. (2016). Pengaruh Kualitas Pelayanan Terhadap Kepuasan Pelanggan Pada JNE. Bandung.
Rangga, M. B. (2013). Pengaruh Kualitas Layanan dan Kepuasan Pelanggan Terhadap Niat Pemakaian Ulang Jasa Service pada Bengkel Toyota Auto 2000. Denpasar.

Sigit, R. D. (2014). Pengaruh Kualitas Pelayanan Terhadap Kepuasan Pelanggan Pengguna Jasa Lapangan Futsal. Bandung.

Tjiptono, F. (2014). Pemasaran Jasa. Surabaya: Andi Published.

Wicaksono, A. W. (2013). Penerapan Metode QFD (QualityFunction Deployment). Yogyakarta.

Wijaya, T. (2018). Manajemen Kualitas Jasa. Edisi 2. Jakarta: Indeks Jakarta.

http://ciputrauceo.net/blog/2015/7/7/pengertian -pelayanan-prima.April.2018

http://www.pengertianahli.com/2014/08/penge rtian-pelayanan-apa-itu pelayanan.html. April.2018 